\title{
The Effect of Financial Risk and Environmental Risk on Mining Company Performance with Good Corporate Governance as Moderating Variables
}

\author{
Sugianto Kusnodiharjo Yvonne Augustine \\ Bussines and Economics Faculty, Trisakti University, PO box 11440, Jakarta, Indonesia
}

\begin{abstract}
The objective of the research is to know and obtain empirical evidence on whether there is an influence between financial risk and environmental risk to mining company performance with Good Corporate Governance as moderating variable. An outline of the practice of business mining processes is given, along with an analysis of the main techniques developed by academics and commercial entities. The data used are A purposive sampling approach was used in selecting the respondents for the study. The statistic method used to test the research hypothesis is a multiple linear regression model, The study identified 6 risk factors contributing to mining project failure. The six most critical mining project risk factors based on both probabilities of occurrence and impact were unstable commodity prices, Inadequate financing, inflation/exchange rate, land degradation, Pollution of air/water bodies, Spread of diseases
\end{abstract}

Keywords: Financial Risk, Environmental Risk, Performance,

DOI: $10.7176 / \mathrm{EJBM} / 11-11-02$

Publication date: April $30^{\text {th }} 2019$

\section{Introduction}

Mining has contributed immensely to the development of many nations. Nevertheless, with growing local and global competition in the often complex industry, the likelihood of achieving desired economic performance is becoming challenging due to a risk of mining failures. It is very critical that governments and firms develop adequate plans to mitigate the effects of these risks. Industry stakeholders need to identify potential mining risk factors, their likelihood, consequences and severities of occurrence. This will enable risk management plans to be developed in order to avoid, mitigate, contain or control these risk factors.

The mining sector has played a significant role in the country's socio-economic development since the colonial period. Though the mining sector has been very supportive of the country's economy over the years, the sector is vulnerable to risks at all levels. The past few years have seen the shutdown of some mining companies in the country resulting from the effects of various risk factors.

The fact that there is a very limited sector-specific risk assessment model for the mining sector is a serious problem. This is because there are specific factors that could influence project success in this sector.

The observations illustrated above call for more in-depth understanding of the types of risks associated with mining projects. For instance, it is very important to address the following issues: what are the critical risk factor's which affect mining projects? Are these risk factors unique to the mining sector or are they similar to risks, which pertain in other sub-sectors of the construction industry? What are the probabilities of occurrence and degree of impact of these risk factors? What measures are mining companies employing to mitigate the effects of these risks? This study relied extensively on the risk assessment approach used by Tummala and Schoenherr (2011), who investigated risks using a supply chain risk management process.

This paper makes an important contribution to the field of mining risk management and highlights an approach to managing these risks from a developing country perspective. There is a need for sector-specific factors to be introduced into existing risk management models. The introduction of these risk factors would ensure that a model suitable to the mining sector can be generated and used to improve project effectiveness and success. According to Esteves de Sousa (2012), each sector has its unique risk factors. As a result, a suitable model of a sector must recognize these unique factors.

Specifically, identified the critical risk issues that affect mining operations, the main purpose of this study, therefore, is to assess the financial risk and environmental risk to mining company performance with Good Corporate Governance as moderating variable.

The European Center for Policy Studies (CEPS), has another formula for GCG. GCG is an entire system that consists of rights, processes, controls, both within and outside the company's management. The rights here are the rights of all shareholders, not just the shareholders. Rights are the various strengths that individual stakeholders have to influence management, the process. The purpose is the transition from these rights, while the changes made involve stakeholders receiving the necessary information regarding various company activities (Daniri, 2017).

The remainder of the paper is organized as follows. The next section discusses previous related studies on 
risk factors in the mining sector. This is followed by a presentation of the methodology of the study. The fourth section discusses the key findings of the study. The fifth section identifies measures for minimizing the most critical mining risk factors. Finally, the research conclusions are presented.

\section{Literature review}

\subsection{Definitions of Risk}

There is no single definition of risk. Economists, behavioral scientists, risk theorists, statisticians, actuaries, and historians each have their own concept of risk (Rejda and McNamara, 2017).

\subsubsection{Traditional Definition of Risk}

Risk traditionally has been defined in terms of uncertainty. Based on this concept, risk is defined as uncertainty concerning the occurrence of a loss. For example, the risk of being killed in an auto accident is present because uncertainty is present. The risk of lung cancer for smokers is present because uncertainty is present. The risk of flunking a required college course is present because uncertainty is present.

Employees in the insurance industry often use the term risk in a different manner to identify the property or life that is being considered for insurance. For example, in the insurance industry, it is common to hear statements such as "That driver is a poor risk" or "That building is an unacceptable risk."

2.1.2 Risk Distinguished from Uncertainty

In the economics and finance literature, authors and actuaries often make a distinction between risk and uncertainty. According to the American Academy of Actuaries, the term risk is used in situations where the probabilities of possible outcomes are known or can be estimated with some degree of accuracy, whereas uncertainty is used in situations where such probabilities cannot be estimated.

2.1.3 Loss Exposure

Because risk is an ambiguous term and has different meanings, many authors and corporate risk managers use the term loss exposure to identify potential losses. A loss exposure is any situation or circumstance in which a loss is possible, regardless of whether a loss actually occurs. Examples of loss exposures include manufacturing plants that may be damaged by an earthquake or flood, defective products that may result in lawsuits against the manufacturer, possible theft of company property because of inadequate security, and potential injury to employees because of unsafe working conditions.

Finally, when the definition of risk includes the concept of uncertainty, some authors make a careful distinction between objective risk and subjective risk.

\subsection{Mining}

Mining is part or all stages of activities within the framework of research, management and exploitation of minerals or coal which includes general investigation, exploration, feasibility studies, construction, mining, processing and refining, transportation and sales, and post-mining activities. Based on the type of mining that is cultivated, mining is divided into four types: mining of radioactive minerals; metal mineral mining; non-metal mineral mining; and rock mining (Undang-Undang no 4 Tahun 2009).

Mining is a process of digging up reserves of mining materials that are in the ground systematically and planned, to obtain products that have economic value (valuable) and can be marketed. Mining is a branch of science that includes the work of searching, investigating, feasibility studies, preparing mining, mining (extracting), processing, exploiting and selling minerals (minerals, coal, geothermal, oil and gas).

Based on the mining system carried out, mining is divided into two types (Sudrajat, 2010): Surface mining is one of two known mining systems, The choice of an open pit system is usually applied to minerals which are relatively close to the earth. Before carrying out excavation or extracting of minerals, you must first carry out preliminary work such as; cleaning of mine plan (land clearing), overburden stripping and digging.

Underground Mine is the selection of mining methods with underground mining systems is largely determined by several technical factors in the geological conditions of the minerals to be mined and other supporting factors. Underground mine is a mining system that refers to the method of extracting mineral materials carried out by making a tunnel to the location of the mineral, where all mining activities are carried out below the surface and not directly related to open air.

Closed Mining is a process of extracting a type of mining item by making a well (vertical mining or Shaf Mining) or tunnel (horizontal mining or Slope Mining) into rock layers because of the location of the mine in the bowels of the earth.

Underwater mining is a relatively new mineral extraction process carried out on the ocean floor. Ocean mining sites are usually around the area of polymetallic nodules or active hydrothermal slits and are at a depth of 1,400 3,700 meters below sea level.

\subsection{Financial Risk}

This risk is related to the company's decision to use debt in financing its capital. The greater the proportion of debt 
used by the company, the greater the financial risk faced by the company. The most influential financial risks in mining are:

2.3.1 Unstable commodity prices

Unstable commodity prices and export income are known to make development planning more difficult and produce adverse short-term effects on income, investment, and employment. In addition, with slow demand conditions, countries that specialize in the production of primary commodities can be estimated to have a declining share in world trade unless they have a high cost or quality advantage over competitors.

\subsubsection{Inadequate financing}

Mining company Local and regional everywhere share the problem of inadequate financing. The main revenue source for financing local and regional development projects in the local and regional budget. The revenue sources for capital projects are limited. The solution for local and regional is to find additional revenue sources for development mining projects. Most mining companies are unprepared or unable to take on increased responsibilities for fund raising directed to economic development.

In order to tackle this challenge a mining company must gain the skills and information needed to budget for the current and future years; the ability to understand the impact of borrowing on infrastructure - both annual debt service and annual operational and maintenance expenditures - and the ability to identify, prioritize and plan capital investment.

Mining company a shortage of investment capital must be able to identify and analyze technical and financial options and show investors that they have adequate and reliable revenues to meet their debt service obligations.

2.3.3 Inflation / exchange rates

For investors who invest in various countries with various currencies, changes in currency exchange rates will be a factor that causes real return to be smaller than the expected return. According to Arifin (2002), foreign exchange is an alternative investment for people who have excess funds, when dollar interest rates rise, investors will flock to sell their shares to be invested in dollars. This will lead to a decrease in stock prices, besides, because the dollar interest rate rises, the Indonesian Central Bank (BI) will immediately increase interest rates, with the aim of preventing people from preferring to hold dollars to rupiah, and this can threatening the Indonesian economy as a whole. The increase in BI interest rates will make many people sell their shares to be placed in banks that can provide a higher rate of return on investment.

\subsection{Environmental risk}

In mining, it is always related to the source taken and involves the environment from the source that causes damage to the environment, the problem is a problem with the environment. Environmental problems in mining land development can be explained in various ways. The following is an environmental problem in the construction of mining land:

2.4.1 Pollution of air/water bodies

In mining and processing, for example, starting from exploration, exploitation, production, purification, processing, transportation, and then selling it can not be separated from hazards such as fire hazards, contamination of the environment by oil materials which cause damage to flora and fauna, pollution due to the use of materials chemicals and the release of gases / vapors into the air in the process of purification and processing.

Environmental pollution as a result of mining management is generally caused by chemical factors, physical factors, biological factors. This environmental pollution is usually more than outside mining. Local land, water, and air conditions in the mine have reciprocal benefits with the environment. For example environmental pollution by $\mathrm{CO}$ is strongly influenced by the diversity of air, pollution by heat stress depends on the conditions of temperature, humidity, and local air flow.

2.4.2 Land degradation

Land degradation is becoming one of the major environmental issues all over the world and affects also developed regions like North America, Australia, and Southern Europe

(Romm 2011). Land degradation is hence an interactive process involving multiple causal factors, among which climate variability, soil quality, and land management play a significant role (Lambin and others 2001; Reynolds and Stafford Smith 2002; Geist and Lambin 2004). In the Mediterranean region, both biophysical variables and socioeconomic conditions affect land quality, and their interaction may become extremely complex through space and time, resulting in typical land degradation patterns (UNEP 1994; MEA 2005a, b).

2.4.3 Spread of Diseases

Mining activity continues to play a key role in the spread of diseases throughout Indonesia. In this study review the evidence about the impact of mining activity. Rich in natural resources, Indonesia contributes significantly to global mining production. The risk of this mining activity to the population spread of diseases is well-established. Miners in Indonesia have a greater incidence of diseases than any other working population in the world. Underground conditions expose miners to a variety of toxins, including silica dust, which causes silicosis, a form of lung disease characterized by scarring of the upper lobes of the lung which can cause respiratory insufficiency. 


\subsection{Definition of terms and stages in risk}

The Project Management Institute (2004) defines risk as an uncertain event or condition that, if it occurs, has a positive or negative effect on a project's objectives. Risk can also be looked at as a "combination of probability or frequency of occurrence of a defined hazard and magnitude of the occurrence". As noted by Tummala and Schoenherr (2011), regardless of the area of interest, a risk is associated with an undesirable loss, i.e. an unwanted negative consequence, and uncertainty.

A very important consideration in properly understanding the concept is the association of uncertainty with risk. In this paper, we conceptualize mining risk as an event that adversely affects mining operation and hence the desired performance measures of the mining sector.

ISO 31000 (2009) considers risk management as the process of anticipating, understanding and deciding whether to modify risk. The risk management process proposed by the Australian Standard for Risk Management and International Organization for Standardization (Risk Management Standard AS/NZS 4360, 1999; ISO 31000 (2009)). This is composed of seven iterative sub-processes of establishing the context of risk, identifying risks, analyzing risks, evaluating risks, communication and consultation across stakeholders and monitoring and controlling risk events (Ahmed et al., 2007). Famiyeh et al. (2015) crystallized these seven iterative steps into three standardized processes, namely, risk identification, risk analysis or measurement and risk evaluation.

Kumar (2010) studied mining companies in India and summarizes the mining investment risks as geology, marketing, finance, administration, government policies, regional/host country issues, environment, and national/political stability. Ernst \& Young (2011/2012) report of business risks facing mining and metals ranked the top-ten mining risks as: resource nationalism, skills shortages, infrastructure access, maintaining a social license to operate (SLO), capital project execution, price and currency volatility, capital allocation, cost management, interruptions to supply, and fraud and corruption.

Badri et al. (2013) also conducted a study on risk management in the mining sector and found that regular risks associated with the mining projects include, fire, mine collapse and vibration associated with long-term problems. Prno and Slocombe (2012) also identified risks in the mining sector to include social risks, environmental risks, and safety risks. Moreover, a study conducted by Chunyan (2012) indicated that risks in the mining sector include geology, market and currency variations, safety incidents, financial peril, and environmental impacts.

All these identified risks could be very challenging to the success of any mining project. Therefore, mining companies must muster these risks, assess and see their likelihood of happening and at what point in the project could happen and come out with measures to prevent them from impacting negatively on mining project sustainability.

\section{Methodology}

The following research methodology was used in between financial risk and environmental risk to mining company performance with Good Corporate Governance as moderating variable. This session presents an overview of the research design.

\subsection{Research design}

The study employed correlation, regression and Smart PLS 3.O analyses. These analysis techniques have complementary properties. While correlation analysis establishes an association among individual variables, regression seeks to identify a causal relationship of these variables and Smart PLS 3.0 finds out the direct and total effect multiple variables have on each other.

The study used both qualitative approaches for data gathering. First, the researchers, through the literature review, identified 6 risk factors which were later placed under two risk categories financial/economic risk: (unstable commodity prices, inadequate financing, inflation and exchange rate;), environmental risk (pollution of air/water bodies, land degradation, spread of diseases) to mining company performance with Good Corporate Governance as moderating variable. Second, a survey was conducted with industry professionals, using a questionnaire, to assess the likelihood of occurrence and degree of impact of the risk factors.

3.1.1 Sampling technique.

A purposive sampling approach was used in determining the sample for the study. The sample comprised key personnel in 15 industries in Indonesia. The total population of major mining firms is 37 . The mining firms were made up of producing mining companies, trading mining companies, and mining consulting companies. And other companies are 20.

3.1.2 Sample characteristics and size.

The respondents were mainly administrators, mining engineers, and project managers. The purposive sampling technique used ensured that person with good knowledge of risk management in the mining sector were surveyed. Of the 62 questionnaires sent to the experts in the 15 industry, 57 were completed and returned representing a response rate of 91.94 percent. 
3.1.3 Questionnaire structure and data analysis. The questionnaire had two main sections. The first section requested for background information about the respondents including gender, educational level, years of experience and profession. The second section of the survey listed the 6 mining risk factors and placed under two categories as follows:

(1) financial/economic risk: unstable commodity prices, inadequate financing, inflation and exchange rate;

(2) environmental risk: pollution of air/water bodies, land degradation, spread of diseases;

\subsection{Analysis of data}

3.2.1 Background information.

The relative importance of the identified risks in the local mining industry is done by examining the observations and judgments of practitioners in the field. Using Gender, level of education, employment position and work experience, it was inferred that the respondents had sufficient knowledge of the relevant 6 risk factors associated with mining. The demographic characteristics of the respondents are shown in Table AI in the Appendix. In one aspect respondents were classified based on the sub-sector or department they work. A breakdown of the respondents is as follows:

- Table I : Gender

\begin{tabular}{|l|r|r|r|r|}
\hline & Frequency & Percent & Valid Percent & Cumulative Percent \\
\hline Male & 29 & 50.9 & 50.9 & 50.9 \\
Women & 28 & 49.1 & 49.1 & 100.0 \\
Total & 57 & 100.0 & 100.0 & \\
\hline
\end{tabular}

Gender : 50.9 percent male and 49.10 percent woman

- Table 2 : Personal background;

\begin{tabular}{|l|r|r|r|r|}
\hline & Frequency & Percent & Valid Percent & Cumulative Percent \\
\hline Staff & 31 & 54.4 & 54.4 & 54.4 \\
Supervisor & 12 & 21.1 & 21.1 & 75.4 \\
Manager & 13 & 22.8 & 22.8 & 98.2 \\
Director & 1 & 1.8 & 1.8 & 100.0 \\
Total & 57 & 100.0 & 100.0 & \\
\hline
\end{tabular}

Staff 54.4 percent, supervisor 21.1 percent, manajer 22.8 percent, direktur 1.8 percent.

- Table 3 : Experience Working

\begin{tabular}{|l|r|r|r|r|}
\hline & Frequency & Percent & Valid Percent & Cumulative Percent \\
\hline $1-5$ & 18 & 31.6 & 31.6 & 31.6 \\
$6-10$ & 15 & 26.3 & 26.3 & 57.9 \\
$11-15$ & 14 & 24.6 & 24.6 & 82.5 \\
$16-20$ & 5 & 8.8 & 5.8 & 91.2 \\
$21-25$ & 3 & 5.3 & 5.3 & 96.5 \\
$>25$ & 2 & 3.5 & 3.5 & 100.0 \\
Total & 57 & 100.0 & 100.0 & \\
\hline
\end{tabular}

Experience working at least five years 31.6 percent, at least ten years 26.3 percent, at least fifteen years 24.6 percent, at least twenty years 8.8 percent, at least 25 years 5.3 percent and over 25 years 3.5 percent.

- Table 4 : Certificate

\begin{tabular}{|l|r|r|r|r|}
\hline & Frequency & Percent & Valid Percent & Cumulative Percent \\
\hline Have & 23 & 40.4 & 40.4 & 40.4 \\
Don't Have & 34 & 59.6 & 59.6 & 100.0 \\
Total & 57 & 100.0 & 100.0 & \\
\hline
\end{tabular}

Have certificate 40.4 percent, dont have certificate 59.6 percent. 
Table 5 : Industry

\begin{tabular}{|l|r|r|r|r|}
\hline & Frequency & Percent & Valid Percent & Cumulative Percent \\
\hline Expedition & 1 & 1.8 & 1.8 & 1.8 \\
IT & 1 & 1.8 & 1.8 & 3.5 \\
Service & 1 & 1.8 & 1.8 & 5.3 \\
KAP & 1 & 1.8 & 1.8 & 7.0 \\
Construction & 2 & 3.5 & 3.5 & 10.5 \\
Consultant & 2 & 3.5 & 3.5 & 14.0 \\
Toys & 1 & 1.8 & 1.8 & 15.8 \\
Manufacturer & 2 & 3.5 & 3.5 & 19.3 \\
Marine & 4 & 7.0 & 7.0 & 26.3 \\
Governance & 1 & 1.8 & 1.8 & 28.1 \\
Printing & 1 & 1.8 & 1.8 & 29.8 \\
Mining & 37 & 64.9 & 64.9 & 94.7 \\
Property & 1 & 1.8 & 1.8 & 96.5 \\
Retail & 1 & 1.8 & 1.8 & 98.2 \\
Trading & 1 & 1.8 & 1.8 & 100.0 \\
Total & 57 & 100.0 & 100.0 & \\
\hline
\end{tabular}

All respondents from 15 industry, the majority from mining $64.9 \%$ and marine $7 \%$

4.1 Discussion of results

This section discusses the results obtained from the analysis of data. The hypotheses were tested by determining the statistical significance of the path coefficients. To evaluate the estimated causal relations, the actual size of each parameter was assessed in terms of the standardized $\beta$ coefficients and $p$-values. All path coefficients in the model were significant at 0.05 level and negative with the exception of the path from diversity barriers factor. Based on these fit indices, we can conclude that overall the model fits the data reasonably well.

The most critical risk factors from financial risk and environmental risk to mining company performance with Good Corporate Governance as moderating variable shown in Figure 1 were unstable commodity prices, inadequate financing, inflation / exchange rates, pollution of air/water bodies, land degradation, spread of diseases.

It would be important for the mining industry to pay critical attention to these risk factors in order to develop appropriate measures to mitigate their effects with Good Corporate Governance. Each of the effect finance risk and environmental risk measures is discussed below. 
- Figure $1:$ Frame

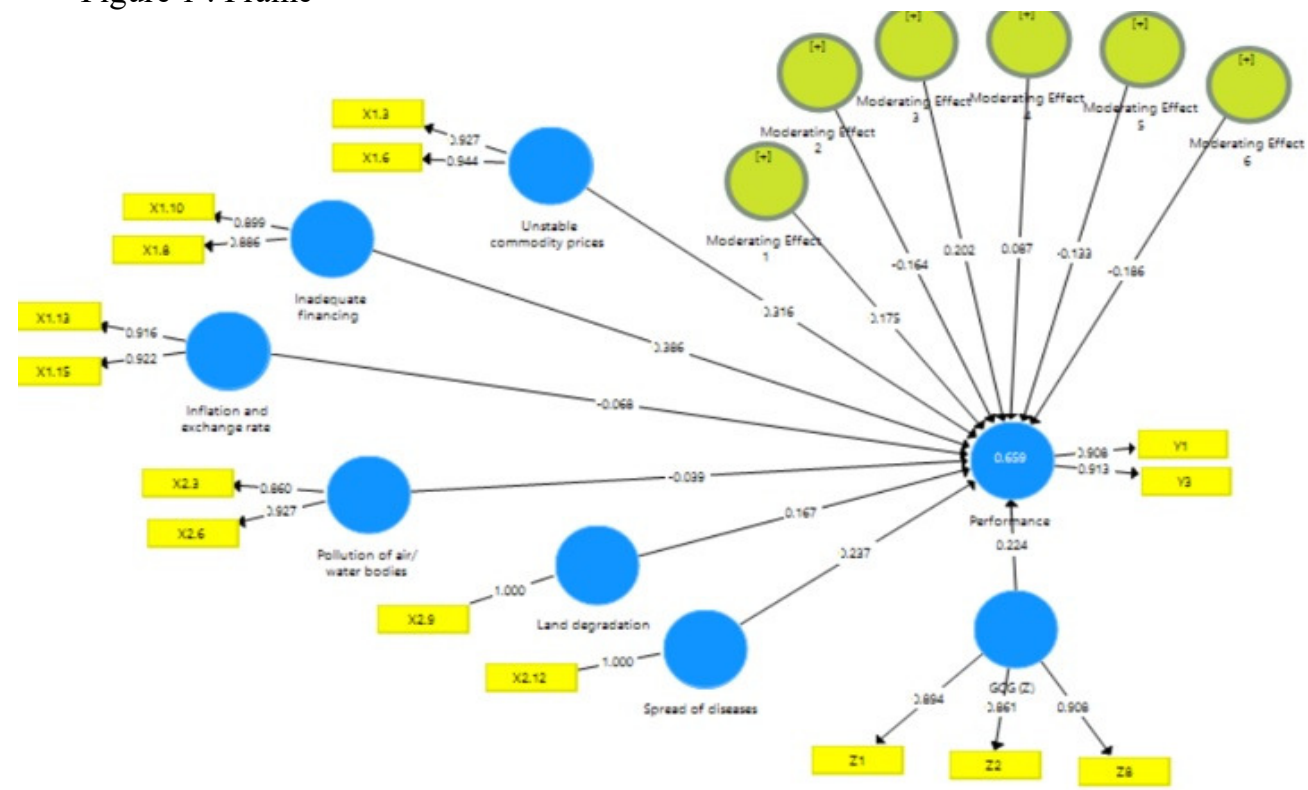

The hypotheses From Figure 1 :

Ha1 : Unstable commodity prices has a negative effect on the performance of mining companies.

$\mathrm{Ha} 2$ : Inadequate financing has a negative effect on the performance of mining companies

Ha3 : Inflation and exchange rate has a negative effect on the performance of mining companies

Ha4 : Pollution of air/water bodies has a negative effect on the performance of mining companies

Ha5 : Land degradation has a negative effect on the performance of mining companies

Ha6 : Spread of diseases has a negative effect on the performance of mining companies

Ha7 : GCG has a positively effect on the performance of mining companies

Ha8: GCG will have a more positively moderating effect between unstable commodity prices on the performance of mining companies.

Ha9 : GCG will have more positively moderating effect between inadequate financing on the performance of mining companies

Ha10: GCG will have more positively moderating effect between inflation and exchange rate on the performance of mining companies

Ha11: GCG will have more positively moderating effect between pollution of air/water bodies on the performance of mining companies

Ha12: GCG will have more positively moderating effect between land degradation on the performance of mining companies

Ha13 : GCG will have more positively moderating effect between spread of diseases on the performance of mining companies

- Table 6: Cross Loading

\begin{tabular}{|c|c|c|c|c|c|c|}
\hline & $\begin{array}{c}\text { Unstable } \\
\text { commodity } \\
\text { prices }\end{array}$ & $\begin{array}{c}\text { Inadequate } \\
\text { financing }\end{array}$ & $\begin{array}{c}\text { Inflation and } \\
\text { exchange rate }\end{array}$ & $\begin{array}{c}\text { Pollution of } \\
\text { air/water bodies }\end{array}$ & Performance & GCG (Z) \\
\hline X1.3 & $\mathbf{0 , 9 2 7}$ & 0,190 & 0,274 & 0,581 & 0,517 & 0,196 \\
\hline X1.6 & $\mathbf{0 , 9 4 4}$ & 0,361 & 0,355 & 0,567 & 0,590 & 0,347 \\
\hline X1.8 & 0,144 & $\mathbf{0 , 8 8 6}$ & 0,588 & 0,087 & 0,473 & 0,353 \\
\hline X1.10 & 0,386 & $\mathbf{0 , 8 9 9}$ & 0,481 & 0,322 & 0,502 & 0,256 \\
\hline X1.13 & 0,294 & 0,451 & $\mathbf{0 , 9 1 6}$ & 0,380 & 0,470 & 0,377 \\
\hline X1.15 & 0,328 & 0,643 & $\mathbf{0 , 9 2 2}$ & 0,357 & 0,488 & 0,476 \\
\hline X2.3 & 0,544 & 0,101 & 0,295 & $\mathbf{0 , 8 6 0}$ & 0,334 & 0,260 \\
\hline X2.6 & 0,554 & 0,289 & 0,407 & $\mathbf{0 , 9 2 7}$ & 0,454 & 0,329 \\
\hline Y1 & 0,579 & 0,329 & 0,420 & 0,504 & $\mathbf{0 , 9 0 8}$ & 0,415 \\
\hline Y3 & 0,503 & 0,663 & 0,528 & 0,315 & $\mathbf{0 , 9 1 3}$ & 0,449 \\
\hline Z1 & 0,370 & 0,219 & 0,302 & 0,417 & 0,450 & $\mathbf{0 , 8 9 4}$ \\
\hline Z2 & 0,151 & 0,372 & 0,452 & 0,196 & 0,410 & $\mathbf{0 , 8 6 1}$ \\
\hline Z8 & 0,255 & 0,321 & 0,497 & 0,262 & 0,400 & $\mathbf{0 , 9 0 8}$ \\
\hline
\end{tabular}


According to kristaung and Augustine (2018), the value of cross loading is significant with the number of 57 samples is 0.75 . then the loading value needed for the level of significance has been fulfilled.

- Table 7: Reliability and validity of data

\begin{tabular}{|l|r|r|}
\hline \multicolumn{1}{|c|}{ Konstruk } & \multicolumn{1}{c|}{ AVE } & \multicolumn{1}{c|}{ Cronbach Alpha } \\
\hline Finance Risk - Unstable commodity prices & 0,876 & 0,859 \\
\hline Finance Risk - Inadequate financing & 0,797 & 0,745 \\
\hline Finance Risk - Inflation / exchange rates & 0,845 & 0,817 \\
\hline Environmental Risk - Pollution of air/water bodies & 0,799 & 0,754 \\
\hline Good Corporate Governance & 0,788 & 0,865 \\
\hline Performance & 0,829 & 0,794 \\
\hline
\end{tabular}

Respondents assigned a value representing likelihood of occurrence for each risk factor. Similarly, an impact or severity value was assigned to each risk factor as required by the Risk Management Standard AS/NZS 4360 (1999). The PLS 3.0 data analysis software was used for processing and analyzing the questionnaire data as well as checking the validity and reliability of the survey results. Cronbach's $\alpha$ of 0.745 was reached. According to Morse et al. (2002), Cronbach's $\alpha$ of 0.70 or more reflects high reliability. It is therefore worth concluding that the study's research instrument was valid.

- Table 8: Path Coefficient

\begin{tabular}{|c|c|c|c|c|c|}
\hline & Original Sample (0) & Sample Mean (M) & Standard Deviation (STDEV) & T Statistics (|O/STDEV|) & P Values \\
\hline GCG $(Z) \rightarrow$ Y Performance & 0.224 & 0.214 & 0.130 & 1.731 & 0.084 \\
\hline Ha1 Unstable commodity prices -> Y Performance & 0.316 & 0.311 & 0.226 & 1.400 & 0.162 \\
\hline $\mathrm{Ha} 2$ Inadequate financing $->Y$ Performance & 0.386 & 0.434 & 0.174 & 2.220 & 0.027 \\
\hline $\mathrm{Ha} 3$ Inflation and exchange rate $\rightarrow Y$ Performance & -0.068 & -0.120 & 0.199 & 0.342 & 0.732 \\
\hline Ha4 Pollution of air/water bodies $\rightarrow Y$ Performance & -0.039 & -0.065 & 0.211 & 0.185 & 0.854 \\
\hline Ha6 Spread of diseases $->$ Y Performance & 0.237 & 0.251 & 0.200 & 1.187 & 0.236 \\
\hline Moderating Effect 1 -> Y Performance & 0.175 & 0.026 & 0.286 & 0.610 & 0.542 \\
\hline Moderating Effect 2 -> Y Performance & -0.164 & -0.159 & 0.217 & 0.758 & 0.449 \\
\hline Moderating Effect 3 -> Y Performance & 0.202 & 0.204 & 0.250 & 0.809 & 0.419 \\
\hline Moderating Effect 6 -> Y Performance & -0.186 & -0.227 & 0.219 & 0.848 & 0.397 \\
\hline
\end{tabular}

The hypotheses were tested by determining the significance of the path coefficients. To evaluate the estimated causal relations, the actual parameters are assessed in terms of the standardized $B$ coefficients and p-values. All path coefficients in the model were significant at 0.05 level and negative with the exception of inadequate financing. Based on these fit indices, we can conclude that overall the model fits the data reasonably well. When the data was examined.

4.1.1 Unstable commodity prices

The analysis showed that the respondents perceived "unstable commodity prices" as the highest risk contributing to mining project failure. Chinbat (2011) ranked this factor as number 8 . has little control over unstable commodity price on the world market. A basic economic law of demand and supply can be used to explain this. If there is a mismatch in the demand and supply of gold, it causes fluctuation in price. The main impact of price fluctuation is uncertainty in revenue to producers, costs to consumers and profit to stockholders. According to Brunetti and Gilbert (1995), high volatility in commodity prices tends to be associated with periods of tight demand and shortterm fluctuations in volatility appear to be associated with speculative movements.

The results Hal accepted: unstable commodity prices has a significant negative effect ( $\mathrm{P}$ values -0.162$)$ to mining company performance and Ha8 were rejected : after with Good Corporate Governance as moderating variable the result becomes high (P Values -0.542). This is because Good Corporate Governance cannot control unstable commodity prices.

4.1.2 Inadequate financing

One of the most common problems of small and/or new businesses is inadequate financing. There are a number of reasons why these businesses do not secure the proper financing before embarking on a new operation. One which emerges repeatedly and that can be readily dealt with is the failure of the owner-manager to prepare a detailed cash flow forecast.

Ventures which need cash flow forecasting the most are those involving rapid and substantial change. Typical situations include: 
- Manufacturing and marketing a new product line.

- Expanding the existing business by opening another new location

- Starting or acquiring and additional business.

Frequently, the most appealing aspect of this type of project is rapid increases in sales. When planning his financing, the owner-manager will to often focus on sales and profit, with some consideration of the fixed asset investment required. What he should do is concentrate on the detailed and total projected cash needs.

The contractual relationship of the agency that occurs to two parties between the principal and the agency (Jensen dan Meckling, 1976). This relationship occurs when one or more principals employ another person called an agent to provide a service in managing the company on behalf of the principal. In practice in companies, investors or company owners are principals, while company management is represented by agents.

According to Jensen dan Meckling (1976) Agency theory explains that the relationship between principals (investor/owner) with management (agent) raises the existence of information asymmetry where this situation can lead to moral hazard, where managers prioritize / secure / benefit their interests rather than the interests of principals with the provision of information that is more known to managers. This is a source of conflict of interest, where investors want large amounts of dividends for investment activities carried out in the company, while company management wants a large salary or bonus. This conflict of interest raises agency costs that can reduce company profits.

The results $\mathrm{Ha} 2$ were rejected : inadequate financing has a significant positive effect ( $\mathrm{P}$ values 0.027$)$ to mining company performance and $\mathrm{Ha} 9$ were rejected : after with Good Corporate Governance as moderation variable the result becomes negative (P Values -0.449). This is because Good Corporate Governance nothing has relations with inadequate financing.

4.1.3 Inflation/exchange rate

The economy has over the years experienced unfavorable exchange and inflation rate trends that have affected the smooth execution of mining projects in a number of ways. The main causes of inflation are increases in monetary aggregates, petroleum price increases, exchange rate depreciation and poor agricultural production. Others include the dollarization of the economy and over-dependence on imports. Even though this risk factor affects mining, the industry it self has little to do in fighting it.

The results $\mathrm{Ha} 3$ accepted : Inflation/exchange rate has a significant negative effect (P values -0.732) to mining company performance and Ha10 accepted : after with Good Corporate Governance as moderation variabel the result becomes better (P Values -0.419). This is because Good Corporate Governance can control inflation/exchange rate with a good standard operational procedure.

4.1.4 Pollution of air/water bodies

The environmental behavior of the residents depends on their perception of environmental pollution. Hence, it is important for scientific and policy experts to research on the impact of the environmental pollution perception of local residents. Owing to the richness of natural resources, Hancheng coal mine areas are abound in heavy industries, and environmental pollution is serious and typical in this area, thus, the residents are anxious about their health. as well as sanitation. This phenomenon can be explained by the various cultural groups having varied perceptions on environmental pollution.

In addition, proximity to mine has a significant negative effect on perceptions of water and noise pollution. The result was the majority of the residents in the coal mine area are not satisfied with their living environment. The perception order of pollution severity is : air pollution $>$ noise pollution $>$ sanitation $>$ water pollution. The residents think that pollution is mainly caused by coal processing. Hence,coal mining is not the main reason for the pollution in the coal mine area.

The results Ha4 accepted : Pollution of air/water bodies has a significant negative effect (P values -0.854$)$ to mining company performance and Ha11 accepted : after with Good Corporate Governance as moderating variable the result becomes small ( $\mathrm{P}$ Values -0.691). This is because Good Corporate Governance improves the environment in the mining areas, environmental pollution must be monitored, and the perception of the local residents on environmental pollution must be understood and considered too. This not only can help government departments to work more efficiently and local residents to respond effectively to the environmental policies of the government but also can provide a reference for environmental management and policy making in the mining areas.

4.1.5 Land degradation

Large-scale mining activities, especially the open cast methods being used now have had a devastating effect on the environment. Hills are graded down, vegetative covers of the soils are stripped and deep excavations are made in order to extract the mineral content underneath. All these have negatively affected people's perception of mining.

In the last decades, due to climate changes, soil deterioration, and Land Use/Land Cover Changes (LULCCs), land degradation risk has become one of the most important ecological issues at the global level. Land degradation involves two interlocking systems: the natural ecosystem and the socio-economic system.

The results Ha5 accepted : Land degradation has a significant negative effect ( $\mathrm{P}$ values -0.306$)$ to mining 
company performance and Ha12 were rejected : after with a Good Corporate Governance as moderating variable the result become better ( $\mathrm{P}$ Values -0.563). This is because Good Corporate Governance can control land degradation with a good standard operational procedure.

4.1.6 Spread of diseases

Mining activity continues to play a key role in the spread of diseases throughout Indonesia. In this study review the evidence about the impact of mining activity. Rich in natural resources, Indonesia contributes significantly to global mining production. The risk of this mining activity to the population spread of diseases is well-established. Miners in Indonesia have a greater incidence of diseases than any other working population in the world. Underground conditions expose miners to a variety of toxins, including silica dust, which causes silicosis, a form of lung disease characterized by scarring of the upper lobes of the lung which can cause respiratory insufficiency. The results Ha6 accepted : Spread of diseases has a significant negative effect (P values -0.236) to mining company performance and Ha13 were rejected : after with Good Corporate Governance as moderating variable the result become better ( $\mathrm{P}$ Values -0.397). This is because Good Corporate Governance can control land degradation with a good standard operational procedure.

4.1.7 Good Corporate Governance

Nothing committed to implementing balanced good corporate governance best practice and upholding employee integrity for sustainable corporate growth, make the company get the negative effect to performance.

Good Corporate Governance (GCG) which contains work relations between Company Organ, Company Principal Policy (GCG Code) and other policies related to GCG, the Company does not implement the items contained in the guidelines. Based on the guidebook which is intended as a guideline, each operational level is not determined to implement GCG in full and possibly possible.

The results $\mathrm{Ha} 7$ were rejected : GCG has a negative effect on the performance of mining companies (P Values $-0.084)$.

\section{Conclusion}

I'm examine financial risk and environmental risk to mining company performance with Good Corporate Governance as moderating variable. document evidence supporting the hypothesis that when risk capacity constraints are binding, corporate governance enhancements serve as a mechanism enabling access to repair performance.

\section{Unstable commodity prices}

Since the economy has little effect on the risk event, mining companies within the country must hedge part of their produce to mitigate the shocks arising from the volatility of commodity prices.

\section{Inadequate financing}

Factors which must be carefully considered when planning new financing, as pointed out in this example, are :

1) Receivables terms

2) Payable terms

3) Inventory Requirements

4) Fixed asset purchase and payable terms

5) Deposits

6) Estimated operating losses

Early and careful consideration of these items will not only allow the owner-manager to determine realistically what his needs are but will often allow him to behave in a fashion which will reduce the total amount in financing needed from bankers and investors.

\section{Inflation/exchange rate}

During the same period, the country saw a decline in mining outputs and laying off of mine workers leading to a complete shutdown of some mining operations. The way around this is to reduce the country's penchant for imported products and promote the use of locally produced goods. It is also important for mining companies to save some of their profits instable foreign currencies in order to avoid the effect of inflation and exchange rate fluctuations on their operations.

Preparing detailed cash flow forecast allows the owner-manager to project his future financing requirements realistically. Cash flow forecasting also helps to eliminate "cash binds" due to unanticipated needs and often suggest innovative methods to reduce the total amount of debt and equity financing required.

\section{Pollution of air/water bodies}

Environmental pollution in mining areas is an external stimulus to residents, and different demographical factors may lead to different environmental pollution perceptions. This may offer some valuable information that can be 
incorporated into decision-making and lead to the resolution of the conflicts in the coal mine area. The main conclusions are as follows:

(1) Residents in the mining areas think that air pollution is the most serious environmental pollution; followed by noise pollution, environmental sanitation, and water pollution.

(2) According to the public perception, environmental pollution in mining areas mainly result from coal processing (washing, screening, and coking) and poor law enforcement (i.e., environmental pollution in mining areas is not mainly caused by coal mining).

A relocation policy should be implemented especially for older people because older residents have a low level of environmental satisfaction. In order to mitigate potential conflicts between the coal mine enterprises and local young people, it also suggests that improving education level for local people should be effective, particularly when coupled with providing employment opportunities. To improve the environment in the mining areas, environmental pollution must be monitored, and the perception of the local residents on environmental pollution must be understood and considered too.

\section{Land degradation}

In order to win community trust and support, the industry must ensure mining companies comply strictly with Environmental Protection Agency's procedures for conserving the environment. There should also be a task force to monitor the activities of these illegal small-scale mine workers. It is also important for mining companies to develop effective land reclamation programs for all mined out areas.

\section{Spread of diseases}

Several basic public health practices and policies could be implemented that would decrease mining-related diseases transmission.

- $\quad$ improving living \& working conditions Conditions on mines vary considerably but are atrocious in many places.

- Underground: providing ventilation \& internationally accepted dust levels In addition to improving the aboveground conditions, mines also need to improve the working conditions that expose miners to a number of well-known toxins.

- Continuity of public health \& medical services : Many miners are migrants. This means that even if they are correctly diagnosed with diseases and put on the right medicine, if and when they leave the mines, they often have trouble accessing their medications in such a way that they do not miss doses or stop taking the medication altogether.

Among the ways, mining companies can ensure continuity of care would be by implementing a system whereby patients themselves carry their health cards with them. This would go a long way towards repairing this vulnerability. Mining companies, in collaboration with government health agencies, could do much more to ensure that their workers and former workers have uninterrupted access to the treatments they need.

\section{References}

Ahmed, A., et al. (2003), “A conceptual framework for risk analysis in concurrent engineering”, Proceedings of the 17th International Conference on Production Research, R1.6 Paper No. 86, Blacksburg, VA, August 4-7.

Achmad, Mas Daniri. 2017. Lead by GCG. Gagas Bisnis. Indonesia

Ali Arifin, 2002, Analisa Bursa Efek, Cetakan kedua, PT. Gramedia Pustaka Utama. Indonesia

AmoateyCharles Teye, FamiyehSamuel, AndohPeter. 2017. Risk assessment of mining projects in Ghana. Journal of Quality in Maintenance Engineering 23:1, 22-38.

Badri, A., Nadeau, S. and Gbodossou, A. (2013), "A new practical approach to risk management for underground mining project in Quebec", Journal of Loss Prevention in the Process Industries, Vol. 26, pp. 1145-1158.

Brunetti, C. and Gilbert, C.L. (1995), "Metals price volatility, 1972-95”, Resources Policy, Vol. 21 No. 4, pp. 237 254.

Chinbat, U. (2011), "Risk analysis in the mining industry, risk management in environment, production and economy", in Savino, M. (Ed.), InTech, ISBN 978-953-307-313-2, available at: www.intechopen.com/books/risk-management-in-environment-production-and-economy/risk-analysisinthemining-industry

Chunyan, G. (2012), “The risks facing China's mining companies - an analysis from global perspective", International Journal of Security and its Applications, Vol. 6 No. 4, p. 131.

Esteves de Sousa, J.M. (2012), "Definition and analysis of critical success factors for ERP implementation projects". Doctoral thesis, Universitat Politecnica de Catalunya, Barcelona, pp. 23-300.

Famiyeh, S and Adaku, E. 2017. Risk assessment of mining projects in Ghana. Journal of Quality in Maintenance Engineering 23:1, 22-38. 
Famiyeh, S., Adaku, E., Kissi-Mensah, L. and Amoatey, C.T. (2015), "Risk management for a tailings re-mining project in Ghana", International Journal of Managing Projects in Business, Vol. 8 No. 2, pp. 241-255, available at: http://dx.doi.org/10.1108/IJMPB-04-2014-0033

ISO 31000 (2009), Risk Management - Principles and Guidelines, International Standards Organisation, Geneva.

Jensen, M. C., \& Meckling, W. H. 1976. Theory of the firm: Managerial behavior, agency costs and ownership structure. Journal of financial economics, 3 (1976): 305-360.

Lambin EF, Turner BL, Geist HJ, Agbola SB, Angelsen A, Bruce JW, Coomes OT, Dirzo R, Fischer G, Folke C, George PS, Homewood K, Imbernon J, Leemans R, Li XB, Moran EF, Mortimore M, Ramakrishnan PS, Richards JF, Skanes H, Steffen W, Stone GD, Svedin U, Veldkamp TA, Vogel C, Xu JC (2001) The causes of land-use and land-cover change: moving beyond the myths. Global Environmental Change: Human and Policy Dimensions 11:261-269.

Kumar, C. (2010), "Risk management in mining projects", available at: www.authostream.com (accessed February 20, 2016).

Kristaung, R. and Augustine, Y. (2018), Metodologi Penelitian Bisnis dan Akuntansi, Dian Rakyat, Indonesia.

Morse et al. (2002). Verification Strategies for Establishing Reliability and Validity in Qualitative Research, International Journal of Qualitative Methods 1 (2) Spring 2002.

Prno, J. and Slocombe, D.S. (2012), "Exploring the origins of 'social license to operate' in the mining sector: perspectives from governance and sustainability theories”, Resources Policy, Vol. 37, pp. 346-357.

Rejda, G. and McNamara, M. (2017), Principles of Risk Management and Insurance, Pearson Education, London. Romm J (2011) Desertification: the next dust bowl. Nature 478:450-451

Sudrajat, Nandang. 2010. Teori dan Praktik Pertambangan Indonesia menurut Hukum. Yogyakarta: Pustaka Yustisia.

Tummala, R. and Schoenherr, T. (2011), "Assessing and managing risks using the supply chain risk management process (SCRMP)", Supply Chain Management: An International Journal, Vol. 16 No. 6, pp. 474-483.

Undang-Undang 4 Tahun 2009 Tentang Pertambangan Mineral dan Batu Bara.

UNEP (1994) United Nations Convention to combat desertification in those countries experiencing serious drought and/or desertification, particularly Africa. UNEP, Geneva. 